Andrews University

Digital Commons @ Andrews University

\title{
The Study Of The Development Of Negation In Bilingual Spanish/ English And Monolingual English Speakers
}

Isabel Cristina Verduzco

Andrews University, verduzci@andrews.edu

Follow this and additional works at: https://digitalcommons.andrews.edu/theses

Part of the Speech Pathology and Audiology Commons

\section{Recommended Citation}

Verduzco, Isabel Cristina, "The Study Of The Development Of Negation In Bilingual Spanish/English And Monolingual English Speakers" (2017). Master's Theses. 107.

https://dx.doi.org/10.32597/theses/107

https://digitalcommons.andrews.edu/theses/107

This Thesis is brought to you for free and open access by the Graduate Research at Digital Commons @ Andrews University. It has been accepted for inclusion in Master's Theses by an authorized administrator of Digital Commons @ Andrews University. For more information, please contact repository@andrews.edu. 


\begin{abstract}
STUDY OF THE DEVELOPMENT OF NEGATION IN BILINGUAL SPANISH/ENGLISH AND MONOLINGUAL ENGLISH SPEAKERS
\end{abstract}

by

Isabel Cristina Verduzco

Adviser: D'Jaris Coles-White, Ph. D. 


\title{
ABSTRACT OF GRADUATE STUDENT RESEARCH
}

Thesis

\author{
Andrews University \\ School of Health Professions
}

\section{Title: THE STUDY OF THE DEVELOPMENT OF NEGATION IN BILINGUAL SPANISH/ENGLISH AND MONOLINGUAL ENGLISH SPEAKERS}

Name of researcher: Isabel Cristina Verduzco

Name and degree of faculty chair: D'Jaris Coles-White, Ph. D.

Date Completed: July 2017

\section{Problem}

Negation is one of the first concepts learned early during childhood and one of the most important ones for communication. Current studies focus on how negation is developed universally in each specific language and how it is governed by patterns of acquisition, however, there are factors that may affect this process. How does learning two languages simultaneously affect the normal development of negation? Analyzing how the exposure to two different languages affects the normal development of negation is important for understanding how bilingualism influences normal language development. This study is also important for the analysis of speech and language as learning how bilingual children develop negation gives clinicians a deeper understanding 
on how to obtain a baseline for distinguishing between a language delay or a language disorder.

\section{Method}

The study was composed by 19 English speaking students from a monolingual elementary school in Southwest Michigan as well as 10 Spanish/English students from a bilingual elementary school in Sacramento, CA. Students were randomly selected from approved consent form received from parents.

Students were individually pulled from their classrooms with the permission of parents and teachers and given a set of preliminary qualifying assessments; the Peabody

Picture Vocabulary Test, $4^{\text {th }}$ Edition (PPVT-IV) for English speaking monolingual children and the Receptive and Expressive One-Word Picture Vocabulary Tests, Fourth Edition (EOWPVT-4) for Spanish/English bilingual children. Participants were required to obtain an average score of $85-115$ to qualify for the study. Following that, children were given a scenario in which two toy cars were shown. The first car was new and shown to the child as a comment was given by saying, "Look at how nice this car is, it is new, it has all its wheels." Then, the students were presented a second toy car missing all its wheels and asked the child, "Look at this second car, what is wrong with it?" The participant was then given the opportunity to respond to the question to express that the car didn't have any wheels.

\section{Results}

The preliminary findings of this pilot study analyzed the data collected by conducting a T-test of variance that demonstrated a significant statistical difference 
between the responses from the monolingual children and the bilingual children. These results are consistent with the study replicated and indicated that monolingual's responses were more consistent with the "Do" inclusion form, while the bilingual responses used the negative form (NEG) + verb + subject construction form in their answers. There was no gender difference significance.

\section{Conclusion}

Bilingualism exposes the case of having to develop two languages at once with one always being more predominant than the other; therefore, it is expected that language development in bilingual children will demonstrate variations from the norm and responses for this experiment will differ between monolingual children and bilingual children. This is an important factor to consider during speech and language treatment and intervention as well as evaluation. For further study, children of different ages and regionally diverse should be considered for investigation. 
Andrews University

School of Health Professions

\title{
THE STUDY OF THE DEVELOPMENT OF NEGATION IN BILINGUAL SPANISH/ENGLISH AND MONOLINGUAL ENGLISH SPEAKERS
}

\author{
A Thesis \\ Presented in Partial Fulfillment \\ of the Requirements for the Degree \\ Master of Science
}

by

Isabel Cristina Verduzco

2017 
CCopyright by Isabel Cristina Verduzco All Rights Reserved 


\title{
THE STUDY OF THE DEVELOPMENT OF NEGATION IN BILINGUAL SPANISH/ENGLISH AND MONOLINGUAL ENGLISH SPEAKERS
}

\author{
A thesis \\ presented in partial fulfillment \\ of the requirements for the degree \\ Master of Science
}

by

Isabel Cristina Verduzco

APPROVAL BY THE COMMITTEE:

Dr. D’Jaris Coles-White, Ph. D., Chair

Tammy Shilling MA, CCC-SLP

Heather Ferguson, MS-CCC/SLP

Date approved 


\section{TABLE OF CONTENTS}

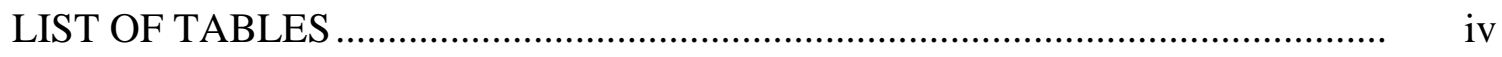

LIST OF ABBREVIATIONS ................................................................

Chapter

1. INTRODUCTION ....................................................................... 1

Purpose of Study ........................................................................... 3

Research Questions and Hypothesis ..................................................... 4

2. DEVELOPMENT OF NEGATION ..................................................... 6

Bilingualism ....................................................................... 9

3. METHOD AND DESIGN ................................................................. 13

Procedure ............................................................................ 16

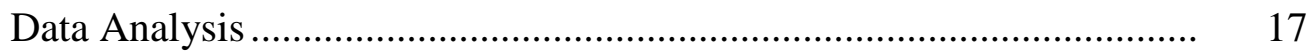

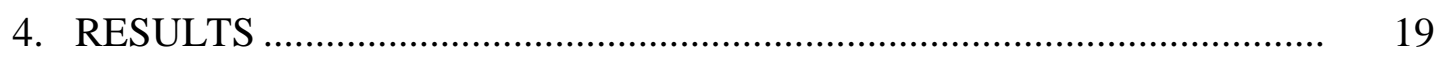

Differences Among Participants on Negative Sentences...................... 19

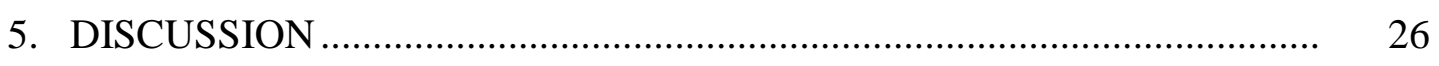

Conclusion ............................................................................... 27

Appendix

A. PARENTAL CONSENT FOR (ENGLISH VERSION) ........................... 29

B. PARENTAL CONSENT FOR (SPANISH VERSION) ........................... 32

C. PARTICIPANTS ASSENT FORM (ENGLISH VERSION) ..................... 35

D. PARTICIPANTS ASSENT FORM (SPANISH VERSION) ...................... 36

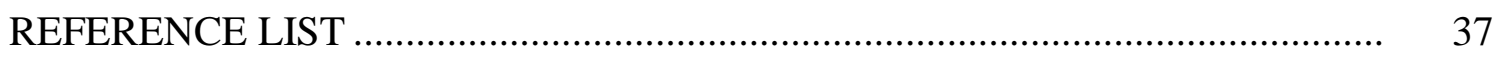




\section{LIST OF TABLES}

1. Klima \& Bellugi's (1966) Negation Patterns of L1 Learners ........................ 8

2. Demographic and Language Assessment Data ......................................... 15

3. Negation Eliciting Question Condition............................................... 17

4. Descriptive Statistics for Experimental Variables ...................................... 20

5. Means and Standard Deviations Descriptive Statistics.............................. 21

6. Mauchly's Test of Sphericity …............................................................. 22

7. Tests of Within-Subjects Effects ........................................................ 23

8. Mean Difference Between Sentences with Negative Element Pairwise

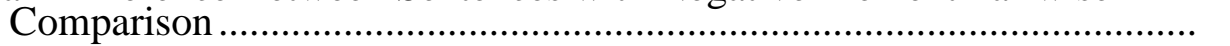




\section{LIST OF ABBREVIATIONS}

$\begin{array}{ll}\text { EOWPVT-4 } & \text { Expressive One-Word Picture Vocabulary Test, Fourth Edition } \\ \text { L1 } & \text { Native Language } \\ \text { L2 } & \text { Second Language } \\ \text { NEG } & \text { Negation Form } \\ \text { NEGSEN } & \text { Negative Sentence } \\ \text { OBJ } & \text { Object } \\ \text { PPVT-4 } & \text { Peabody Picture Vocabulary Test, } 4^{\text {th }} \text { Edition } \\ \text { U } & \text { Utterance }\end{array}$




\section{CHAPTER 1}

\section{INTRODUCTION}

Children's language acquisition is a topic widely studied by many researchers, linguists and educational professionals. Many researchers spend their time assembling a variety of methodologies to uncover the mechanisms underlying all aspects of language acquisition (Saffran, Senghas, \& Trueswell, 2001). Within the areas of language

development, there are topics which have been widely studied while others are still being investigated.

Bilingualism is a relevant topic of study that many researchers have undertaken as it is generally believed that more than half of the world's population is bilingual. In each of the U.S. and Canada countries, approximately $20 \%$ of the population speaks a language at home other than English. In Europe, bilingualism is even more prevalent: In a recent survey, $56 \%$ of the population across all European Union countries reported being functionally bilingual, with some countries recording particularly high rates, such as Luxembourg at $99 \%$. In the United States, it is predicted that by the year 2025, there will be about five million Spanish speaking children under age five (Sun-Alperin \& Wang, 2011). Studies have also revealed that $80 \%$ of bilingual children enrolled in public school report Spanish to be the primary home language (Kindler, 2002), making Spanish the most common language other than English to which children are exposed (Cycyk, Bitetti, \& Hammer, 2015). Bilinguals, therefore, conform a significant portion of the population. 
Studies have indicated that parallels of learning two languages are significant for some children, but detailed analysis on specific topics is still absent (Madrid \& Garcia, 1981). Other research has shown that the development, efficiency, and decline of crucial cognitive and language abilities are different for bilinguals than for monolinguals (Bialystok, Craik, \& Luk, 2012). For this reason, recently the topic of bilingualism has received more attention from researchers working in the field of second language acquisition, especially the analysis of the role of the native language (L1) in the second language (L2) acquisition as well as studies of any positive or negative impacts each may pose (Larrañaga, Treffers-Daller, Tidball, \& Ortega, 2012).

In light of this evidence, studies comparing the language development of monolingual and bilingual children are important as they give information that will be useful in all areas of psycholinguistics, not only for educators but also for clinicians.

A study by Madrid and Garcia (1981), showed analysis of second language acquisition (Spanish/English) and suggested that children's performance in English (the second language) reflected Spanish language constructions. This is the theory of language transfer, which states that second language learners tend to rely on the structures of their L1 when speaking and using L2 and use transferable language structures that impact syntactic productions of language (Brogan \& Son, 2015).

Negation is a particular syntactic structure that has been vastly studied in monolingual children. There is an extensive amount of research that has investigated how negation develops and how it is used in language, as demonstrated in relevant studies by several researchers such as Choi (1988), Déprez and Pierce (1993), Drodz (2002), Gilkerson, Hyams, and Curtiss (2004), Givón (1978), Haegeman (1995), Horn (2001), 
Laka (1994), McNeill and McNeill (1967), Ouhalla (1990), Pea (1980), Thornton and Tesan (2013), van Gelderen (2010), Zanuttini (1997), Zeijlstra (2004), and WaltonRamirez (2015) to name a few.

Despite this extensive research, relatively little work has been done on how second language acquisition affects the normal patterns of negation development. Therefore, the topic of Spanish/English language acquisition, especially as it relates to the construction of negation, is an intriguing area for research due to its differential syntactic structures across both languages (Madrid \& Garcia, 1981). Research that studies monolingual children language development has served as a benchmark and comparison for recent bilingual studies that seek to reach an understanding of the developmental trends for different linguistic structures that children use in their language (Madrid \& Garcia, 1981).

\section{Purpose of Study}

The purpose of this study is to systematically offer an extended analysis of bilingual acquisition with particular emphasis on the development of negation. It attempts to make a comparison of English constructions of negatives by Spanish/English bilinguals and monolingual English speaking children under specific conditions created by the researcher. It will focus on isolating the differences of these negation constructions cross-sectionally for Spanish/English bilinguals and English monolinguals across age levels of four to five-year-old, providing a hypothesis testing concerning the mental organization and language transfer theories.

The primary focus is to compare the construction of negatives from four to fiveyear-old children in relation to the three stages of negation development proposed by 
Klima and Bellugi (1967): (a) Negative form (NEG) + utterance (verb or subject) sequences, (b) "Do" inclusion and (c) subject inclusion.

The prediction for monolinguals is based on the theory exposed by Dulay and Burt (1972) is that the negative agent verb will progress from the NEG + utterance to the use of no, not, can't or don't in a position preceding the verb which in turn will progress from this form to a more complex auxiliary verb contraction used before the main verb and inclusion of the subject.

For bilinguals, based on the prediction made by Lambert and Rawlings, (1969) a transfer theory predicts differential errors for Spanish/English bilinguals for English: (a) NEG + utterance (verb or subject) sequence should follow Spanish construction strategies and emerge as NEG + verb + utterance, (b) "Do" inclusion forms may be infrequent since the do support does not exist for the Spanish and (c) transfer would also be reflected by the omission of sentence subjects in English, since it is permissible in Spanish to omit subjects. (Madrid \& Garcia, 1981).

It is also expected that construction of negatives in Spanish will also reflect language transfer from English since language interaction is a reciprocal process. (Madrid \& Garcia, 1981).

\section{Research Questions \& Hypothesis}

For this proposed research, the focus will be on the linguistic component in the area of negation. The question and hypotheses for this research study are as followed:

Question 1: Do bilingual and monolingual four to five-year-old children differ in the construction of negative sentences?

Hypothesis 
$\mathrm{H}_{0}$ : There is no difference between the responses of monolingual and bilingual children during the construction of negation.

$\mathrm{H}_{1}$ : There is a difference between the responses of monolingual and bilingual children during the construction of negation.

These questions will help obtain more information on the construction of negation in Spanish/English bilingual children and investigate the impact of Spanish language transfer in their responses. 


\section{CHAPTER 2}

\section{DEVELOPMENT OF NEGATION}

Negation is a widely known topic in language studies. It is part of the syntactic structure of language that has been extensively studied in monolingual individuals. However, it has been difficult to establish specific patterns when it comes to second language learners due to the variety of influencing factors. Since this study seeks to compare how monolinguals and bilinguals construct negation, it is important to explore the used patterns of construction.

English speakers demonstrate three major stages in the acquisition of negation. According to Klima and Bellugi (1966), Bloom (1970), Wode (1977), and Capdevila i Batet and Llinás i Grau (1995), these stages can be summarized as follows:

Stage I: One-word negation. In this early stage, children tend to use a NEG which is usually the word no and sometimes not, at the front or the end of an utterance. It is important to emphasize that negatives will not be found in the sentence but only before or after. For example, it is seen utterances such as "No wheels" or "No have wheels". Thus, it is seen utterances of the form: NEG + Utterance(U) or U + NEG. Klima and Bellugi (1966) noted that the productions of negation varied considerably from child to child in monolingual cases.

Stage II: Multi-word negation with NEG in external position using "Do" auxiliaries. In this stage the child uses negative markers such as no, not, can't, don't in 
the utterance internally with verb stems and modals, and less in utterance-initial position (Wode, 1977). Auxiliary verbs can be seen in combination with the negative marker, as in don't and can 't, but not in questions or declarative utterances at this stage (Klima \& Bellugi 1966). According to Steinberg (1993), utterances at this stage are still not completely developed and negative imperatives are still poorly formed. This is exemplified in the following productions: a. I don't want it. b. We can't talk. c. Don't leave me. d. He no bite you.

Stage III: Subject inclusion with clause-internal negation. At this stage, the child has a good idea of when the word do must be inserted and when it should not. The use of questions and declarative sentences as well are more defined in form of responses. The child makes placement errors but seems to grasp the basic notion that the word do is not added when there is a modal like can't or will, or when be is the verb. After this period, it is only a matter of months before most of the problems in negative making are successfully dealt with (Steinberg 1993, p. 16). A study by Cameron-Faulkner, T., Lieven, E., and Theakston, A. (2007), states that "by stage 3, the child is considered to have an adult-like command of negators". Some examples of these type of utterances are "The car doesn't have wheels" which demonstrates a more adult-like form of negation compared to stage I or II.

Table 1 illustrates the three stages of negation patterns in L1 learners. 
Table 1

Klima \& Bellugi's (1966) Negation Patterns of L1 Learners

\begin{tabular}{c|l|l}
\hline \multicolumn{1}{c}{ Stage } & \multicolumn{1}{c}{ Pattern } & \multicolumn{1}{c}{ Examples } \\
\hline 1 & Not $]+$ utterance (verb or subject) & No have wheels \\
3 & Do (auxiliary) Inclusion & It doesn't have wheels \\
& Subject Inclusion & The car has no wheels \\
\hline
\end{tabular}

A study by Lindholm and Padilla (1977), presents the English adult negative structure as having two transformations inherent in this modality called "Negative Transportation”, which involves moving the negative element from the beginning of the sentence to a position behind the auxiliary verb. The second transformation is the: "Do Support". If no auxiliary verb is present in the sentence, the insertion of " $d o$ " is obtained by this rule. Therefore, the declarative sentence: "He wants something" could be transformed to a negative in the following ways: "He wants (neg) something (neg)", or "He doesn't want something (neg)" or "He doesn't want anything".

In the Spanish negative system, negation is always inserted before the verb phrase by negative transformations. However, it takes the following two forms: "no" is inserted before the verb when there is no pro-verbal element that can take a negative form or "negative spread" which occurs when there is a preverbal element capable of taking the negative form. The preverbal element is inserted before the entire verb phrase and then dictates that a negative be attached throughout the verb phrase 
wherever it can be accepted. The negative elements include "nadie", "nada", "nunca", "ningun", etc. words meaning "nobody", "nothing", "never", and "none" respectively. Thus, the declarative sentence: "El quiere algo" or "He wants something", would be transformed to: "El no quiere algo (Negative transfer)" or "El no quiere nada (Negative spread)" which means “He doesn't want something” or "He doesn't want anything" (Padilla \& Lindholm, 1976)

In summary, it is seen that both Spanish and English apply the negative transformation rules, however, the end result is different in both languages.

\section{Bilingualism}

A division of learners' errors according to whether they appear to originate from an L1 structure or L2-dependent rule construction has formed the mainstay of studies of L2 learner-language for many years. (Zobl, 1980) Of course, the acquisition of two linguistic systems might in itself influence the development of syntactic acquisition variables, especially if syntactic forms differ across languages. According to Dulay and Burt (1972), one of the theories about second language acquisition suggests that bilingual children organize their language and make generalizations about its structure in the same way as children learning their first language. Therefore, the negation errors in the second language will be similar to those of children learning the same language natively. This would mean that errors will be similar in both languages. This theory is called the Mental Organization theory.

A second theory about second language acquisition proposed by Garcia et al. (1977), suggests that by the time a child is learning a second language, he or she will use language structures from his native tongue in the new language. In this case, any 
errors made in the construction of Spanish negatives will transfer into constructions of negatives in the English language. This thinking is based on the theory of language transfer.

It is seen that when it comes to second language acquisition as it relates to negation, a number of studies have explored different theories offering patterns that can provide insight into the development of this area. Some studies have explored the development of negation seeking to provide insight into how negation is acquired and developed by second language learners. Some researchers have explored where the various stages fall within the conventional breakdown in second language learners and bilingual individuals. (Ahmad, 2002)

Others have introduced the possibility that learner errors in negation may not be just transfers from the first language but a case in which the learner cognitively tries to determine the L2 structure and in the process creates an interlanguage of developmental sequences containing various stages that often include grammatically incorrect structures. (Ahmad, 2002)

A study by Anaya, Pena, and Bedore (2016) presented the idea of distributed knowledge. Distributed knowledge is demonstrated when bilingual children appear to have gaps in their vocabulary and semantic knowledge due to the fact that they use language for different purposes and in different contexts. They know the words for specific functions in their native language but do not see the need to use that word in their second language.

Researchers have also studied different factors that impact the proficiency and language ability in bilingual children. It is of knowledge that bilingual children 
underperform in academic content areas, (Duran \& Weffer, 1992; Garcia \& Miller, 2008; Reardon \& Galindo, 2009) as data confirms that Latino students perform lower on measures of math and reading in fourth and eighth grades (Hemphill \& Vanneman, 2011) and are more likely to drop out of high school than non-Latino students (Chapman, Laird, Ifill, \& KewalRamani, 2011). Some existing factors have been suggested that are very important to include when studying this topic; the differences in the amount of exposure from both languages or one and maternal education are two important factors to consider. Many of these children live in homes in which the English language is not spoken. This fact may significantly affect their proficiency and development of the English language. Another factor that may contribute toward not favorable predictions is the social economic status of the student as it heightens academic risk. (Duran \& Weffer, 1992) Statistics mentioned that $34 \%$ of Latino children in the United States fall below poverty line (Aud et al., 2012) as 30\% of Latina women and mothers have less than a high school education (McGuire, 2011). Lastly, the social-emotional context of the home environments may also influence language development. The emotional health of the caregiver in cases of depression or lack of social support have a strong impact. (Ryff \& Keyes, 1995) The relationship between the child and the caregiver impacts general language acquisition. Further investigation on how these factors affect the development of negation in bilingual children would be useful.

Bilingual children's exposure to their two languages can be captured in several ways. These include the length of time that they have lived in the country, the age at which they were regularly spoken to in their L2, and the languages that parents and teachers use when talking with the children. (Hammer et al., 2012) 
Language is an innate ability that is developed as a set of specific rules which would demonstrate that each language develops individually and without much interaction. Dulay and Burt (1974) reported a very low percentage of linguistic errors in children learning English as a second language. These same children also demonstrated normal errors in their native language. Based on these findings, it has been determined that errors observed during second language acquisition were related to developmental language processes and not to language transfer. (Madrid \& Garcia, 1981). Empirical evidence for the relationship between the two language domains has been obtained on the basis of early language development (Fenson et al., 1994) and in children with LI, both English speakers (Rice, Wexler, Marquis, \& Hershberger, 2000; van der Lely, 2005) and bilinguals (Castilla, Restrepo, \& Perez-Leroux, 2009; Conboy \& Thal, 2006; Marchman, Martínez-Sussman, \& Dale, 2004). Most studies suggest strong association between the two domains, although there is also research supporting their relative disassociation on the basis of disproportional semantic and grammatical deficits in children with LI, for example (van der Lely, Rosen, \& McClelland, 1998).

The evidence all these studies provide make it possible that any of these theories could be reflected in the responses given by the bilingual children. It could be possible that any of the theories of language transfer or other trends mentioned above could be reflected in the constructions of negatives being observed in this study. 


\section{CHAPTER 3}

\section{METHOD AND DESIGN}

In this study to compare how monolinguals and bilinguals construct negation, the participants were comprised of 19 monolingual English speaking children and 10 bilingual Spanish/English children, between ages 4.0 to 5.6 years old. The monolingual participants were recruited from two approved locations in Michigan; The Crayon Box (Berrien Springs, Michigan) and Bridgman Elementary (Bridgman, Michigan) and the bilingual children from an approved location in California; Sacramento Unified Schools. After approval from the Andrews University Institutional Review Board, consent forms were sent to parents of the children enrolled in the Crayon Box and the Bridgman Elementary school as recruitment strategies.

The exclusionary criteria included hearing impairments, vision impaired, cognitive impairments of any kind (mentally challenged, traumatic brain injuries etc.), severely language impaired (as determined by the Peabody Picture Vocabulary Test $4^{\text {th }}$ edition [PPVT-4]) and gifted children (information from the general education teacher and scores on the PPVT-4).

To determine expressive and receptive language ability, an assessment was carried out for all participants using the PPVT-4 in the monolingual children and the Expressive One-Word Picture Vocabulary Test, Fourth Edition (EOWPVT-4) in the bilingual children. The PPVT-4) was used as this test is known as a highly reliable and 
valid measure of language. This test was used for the monolingual participants as it is an individually administered and norm-referenced assessment that offers an accurate measure of language proficiency and language ability through a comparison between receptive and expressive vocabulary performance. An average score of 85-115 was required to confirm eligibility for the study. By administering this test during our study, the researcher sought to find similar levels of language aptitude in all children, monolingual or bilingual.

To determine expressive and receptive language ability in the bilingual children, participants were given the EOWPVT-4. The Receptive One-Word Picture Vocabulary Test and EOWPVT-4 was used since it is highly correlated with the PPVT and therefore the participants were assessed with similar assessment measures. This test is also individually administered, norm-referenced assessment to target the ability to understand the meaning of words and delivers a comparison of a child's receptive and expressive vocabulary skills. The test takes about 15-20 minutes to administer and it has been standardized on English-speaking individuals from ages 2 through 80+ years residing in the United States. An average score of 85-115 was expected when compared to native English speakers of chronological age and required to meet eligibility to participate in the study.

Participants were then asked to provide information regarding age, gender and grade.

Table 2 provides information regarding the age, gender and grade of the participants. 
Table 2

Demographic and Language Assessment Data

\begin{tabular}{llll}
\hline Gender & Language & Age & Grade \\
\hline M & Bilingual & $4 ; 0$ & \\
M & Bilingual & $4 ; 1$ & Preschool \\
F & Bilingual & $4 ; 1$ & Preschool \\
M & Bilingual & $4 ; 4$ & Preschool \\
M & Bilingual & $4 ; 5$ & Preschool \\
F & Bilingual & $4 ; 9$ & Preschool \\
M & Bilingual & $4 ; 10$ & Preschool \\
F & Bilingual & $5 ; 4$ & Preschool \\
F & Bilingual & $5 ; 5$ & Preschool \\
M & Bilingual & $5 ; 6$ & Preschool \\
F & Monolingual & $4 ; 9$ & Preschool \\
M & Monolingual & $4 ; 9$ & Preschool \\
F & Monolingual & $4 ; 9$ & Preschool \\
F & Monolingual & $5 ; 1$ & Preschool \\
F & Monolingual & $5 ; 1$ & Preschool \\
M & Monolingual & $5 ; 1$ & Preschool \\
M & Monolingual & $5 ; 1$ & Preschool \\
M & Monolingual & $5 ; 1$ & Preschool \\
F & Monolingual & $5 ; 2$ & Preschool \\
F & Monolingual & $5 ; 2$ & Preschool \\
F & Monolingual & $5 ; 3$ & Preschool \\
F & Monolingual & $5 ; 3$ & Preschool \\
M & Monolingual & $5 ; 3$ & Preschool \\
F & Monolingual & $5 ; 4$ & Preschool \\
M & Monolingual & $5 ; 4$ & Preschool \\
F & Monolingual & $5 ; 4$ & Preschool \\
F & Monolingual & $5 ; 4$ & Preschool \\
F & Monolingual & $5 ; 5$ & \\
F & Monolingual & $5 ; 6$ & \\
Note. Mool & \\
\hline
\end{tabular}

All participants obtained a score between $85-115$ that qualified them to be part of the study.

Apart from these assessments, a language sample was also conducted to get an overall view of the children's language capabilities. The importance of language sample 
analyses (e.g., Gutiérrez-Clellen, Restrepo, Bedore, Peña, \& Anderson, 2000; Restrepo, 1998) was presented by a study which determines that these are currently some of the best available measures of children's language abilities in Spanish for diagnostic purposes.

These assessments were administered to ensure all children demonstrated a similar level of language ability so that the data collection would demonstrate the construction of negation from average levels.

\section{Procedure}

A specific scenario was set for all the participants to elicit a form of negation in response to a question. The procedure was carried out in an enclosed quiet classroom at the schools, in which the participant was seated beside the examiner. The following stimulus items were used for the experimental task: three cars with removable wheels. These items were selected as they seemed to be commonly used by children of three to six-year-old.

The stimulus items were selected specifically to facilitate the expression of negation.

Negation was elicited as follows: A brand new toy car was shown to the participant followed by the comment: "See this nice car how nice it is? It has all its wheels." Then, a second toy car was shown to the child with its wheels removed followed by the comment: "What's wrong with this car?" Bilingual subjects were presented with the same dialogue delivered in their language of dominance. The order of language presentation and the order of item presentation will be determined randomly for 
each subject. At the end of each individual session, the child will be given a reward for his or her cooperation.

Table 3 describes the scenario given to elicit negation.

Table 3

Negation Eliciting Question Condition

Comment 1: Condition:

1. "Look at how nice this car is, it has all its wheels!"

Comment 2:

2. "And now look at this car!"

\section{Question 3:}

3. What is wrong with it?

\section{Data Analysis}

The participant's responses were categorized according to the three major stages in the acquisition of negation sugested by Klima and Bellugi (1966), Bloom (1970), Wode (1977), and Capdevila and Llinás (1995). These three stages were: (a) NEG + U (verb or subject) sequences, (b) "Do" inclusion and (c) subject inclusion. All responses were analyzed and categorized accordingly in an excel sheet. If a response not specified by these categories was given, it was listed under the "other" response column.

The data was organized in an excel sheet which also included the gender, age and language of dominance and then analyzed with the program Statistical Package for the Social Sciences. 
A correlation analysis was conducted between the utterance responses of the English monolinguals and the Spanish/English bilinguals to determine the significance of difference. To obtain this information, various tests were conducted to determine the interconnection between the variables. A one-way repeated measures analysis of variance (ANOVA) was conducted to observe the effects of the primary language on the productions of negatives, a Mauchly's test of sphericity was also completed. This test is usually done to prove that the level of dependence between pairs of groups is roughly equal. Finally, a four paired samples t-tests (i.e., pairwise comparisons) were used to make post hoc comparisons between types of sentences with negative elements used within subjects. 


\section{CHAPTER 4}

\section{RESULTS}

In the study to compare how monolinguals and bilinguals construct negation, the responses from monolingual and bilingual children were obtained and an analysis of the negative constructions was conducted. The preliminary findings of this pilot study analyzed the data collected by a variety of tests that demonstrated a significant statistical difference between the responses from the monolingual children and the bilingual children. These results are consistent with the study replicated and indicated that monolingual's responses were more consistent with the "Do" inclusion form, while the bilingual responses used the NEG + U construction form in their answers. There was no gender difference significance.

\section{Differences Among Participants on Negative Sentences}

Results of this pilot study replicating the effects of primary language spoken (bilingual Spanish and English; monolingual English) on producing sentences with negation revealed that there were differences. Table 4 shows the descriptive statistics of case summaries for the experimental variables. Case summaries show that bilingual and monolingual participants produced four different types of sentences with negative elements. An ANOVA was conducted to compare the effect of primary language spoken 
Table 4

Descriptive Statistics for Experimental Variables

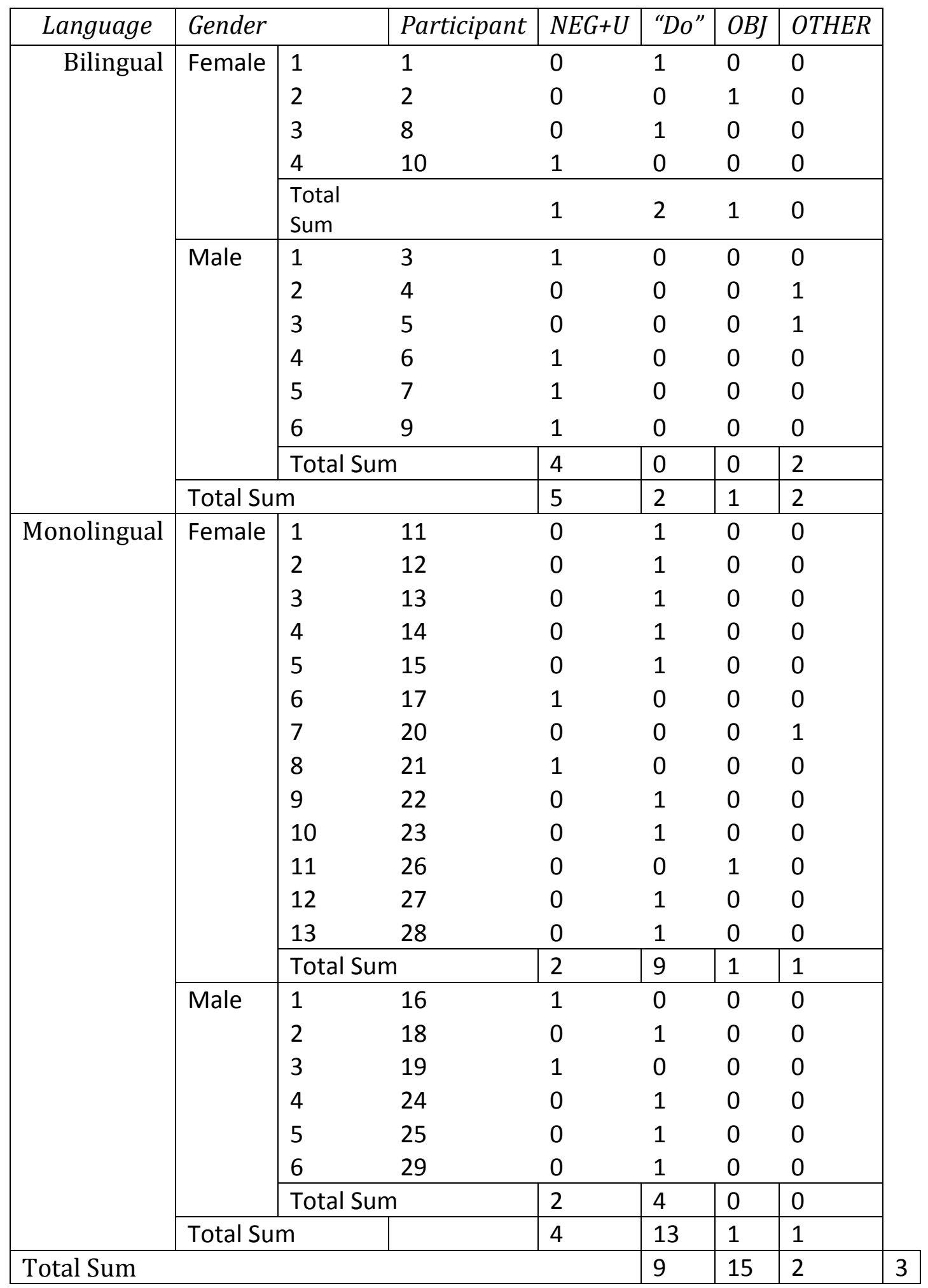


(bilingual, monolingual) on speaker's production of the four types of sentences with negative elements (i.e., $\mathrm{NEG}+\mathrm{U}$, auxilary “ $D O$ ", object (OBJ), and other). Table 5 shows the means and standard deviations of the experimental variables.

Table 5

Means and Standard Deviations Descriptive Statistics

\begin{tabular}{llrrr}
\hline & Language & Mean & $\begin{array}{c}\text { Std. } \\
\text { Deviation }\end{array}$ & N \\
NEG +U & Bilingual & 1.50 & .527 & 10 \\
& Monolingual & 1.21 & .419 & 19 \\
"DO" & Total & 1.31 & .471 & 29 \\
& Bilingual & 1.20 & .422 & 10 \\
& Monolingual & 1.68 & .478 & 19 \\
OBJ & Total & 1.52 & .509 & 29 \\
& Bilingual & 1.10 & .316 & 10 \\
& Monolingual & 1.05 & .229 & 19 \\
OTHER & Total & 1.07 & .258 & 29 \\
& Bilingual & 1.20 & .422 & 10 \\
& Monolingual & 1.05 & .229 & 19 \\
& Total & 1.10 & .310 & 29 \\
\hline
\end{tabular}

Mauchly's test indicated that the assumption of sphericity (i.e., that the variances of the differences between experimental variables conditions are equal) was violated, $\chi^{2}(5)=$ 13.023, $p=.023$ therefore degrees of freedom were corrected using Greenhouse-Geisser estimates of sphericity $(\varepsilon=.75)$. Table 6 shows Mauchly's Test of Sphericity. The tests of within subjects' effects (ANOVA) confirmed that there was significant effect of primary language spoken on type of sentence with negative elements, $F(3,61)=4.196, p$ $=.016$. Thus, results suggest that bilingual and monolingual participants produce some 
Table 6

Mauchly's Test of Sphericity

\begin{tabular}{lrrrrrrr}
\hline MEASURE_1 & & & & & & \\
Within & Mauchly's & $\begin{array}{c}\text { Approx. } \\
\text { Subjects }\end{array}$ & W & df & Sig. & \multicolumn{3}{c}{$\begin{array}{l}\text { Epsilon } \\
\text { Effect }\end{array}$} & & Chi-Square & & & $\begin{array}{c}\text { Greenhouse- } \\
\text { Geisser }\end{array}$ & $\begin{array}{c}\text { Huynh- } \\
\text { Feldt }\end{array}$ & $\begin{array}{c}\text { Lower- } \\
\text { bound }\end{array}$ \\
\hline $\begin{array}{l}\text { Negative } \\
\begin{array}{l}\text { Sentence } \\
\text { (NegSen) }\end{array}\end{array}$ & .603 & 13.023 & 5 & .023 & .750 & .852 & .333 \\
\hline
\end{tabular}

Tests the null hypothesis that the error covariance matrix of the orthonormalized transformed dependent variables is proportional to an identity matrix.

a. Design: Intercept + Language

Within Subjects Design: NegSen

b. May be used to adjust the degrees of freedom for the averaged tests of significance. Corrected tests are displayed in the Tests of Within-Subjects Effects table.

types of sentences with negative elements more than others. Table 7 shows the ANOVA for within-subjects experimental variables.

Four paired samples t-tests (i.e., pairwise comparisons) were used to make post hoc comparisons between types of sentences with negative elements used within subjects. Results showed a significant difference between sentences with negative elements.

Sentences with Neg $+\mathrm{U}$ differed significantly from sentences with subject inclusion, $p=$ .20 ; sentences with "Do" inclusion differed significantly from sentences with subject inclusion, $p=.004$; and sentences with negative elements labeled as Other differed significantly from sentences with Aux DO, $p=.015$. Table 8 shows the mean difference between the four sentences with negative elements. Figure 1 shows the plot of means for type of sentence with negation by language spoken. 
Table 7

Tests of Within-Subjects Effects

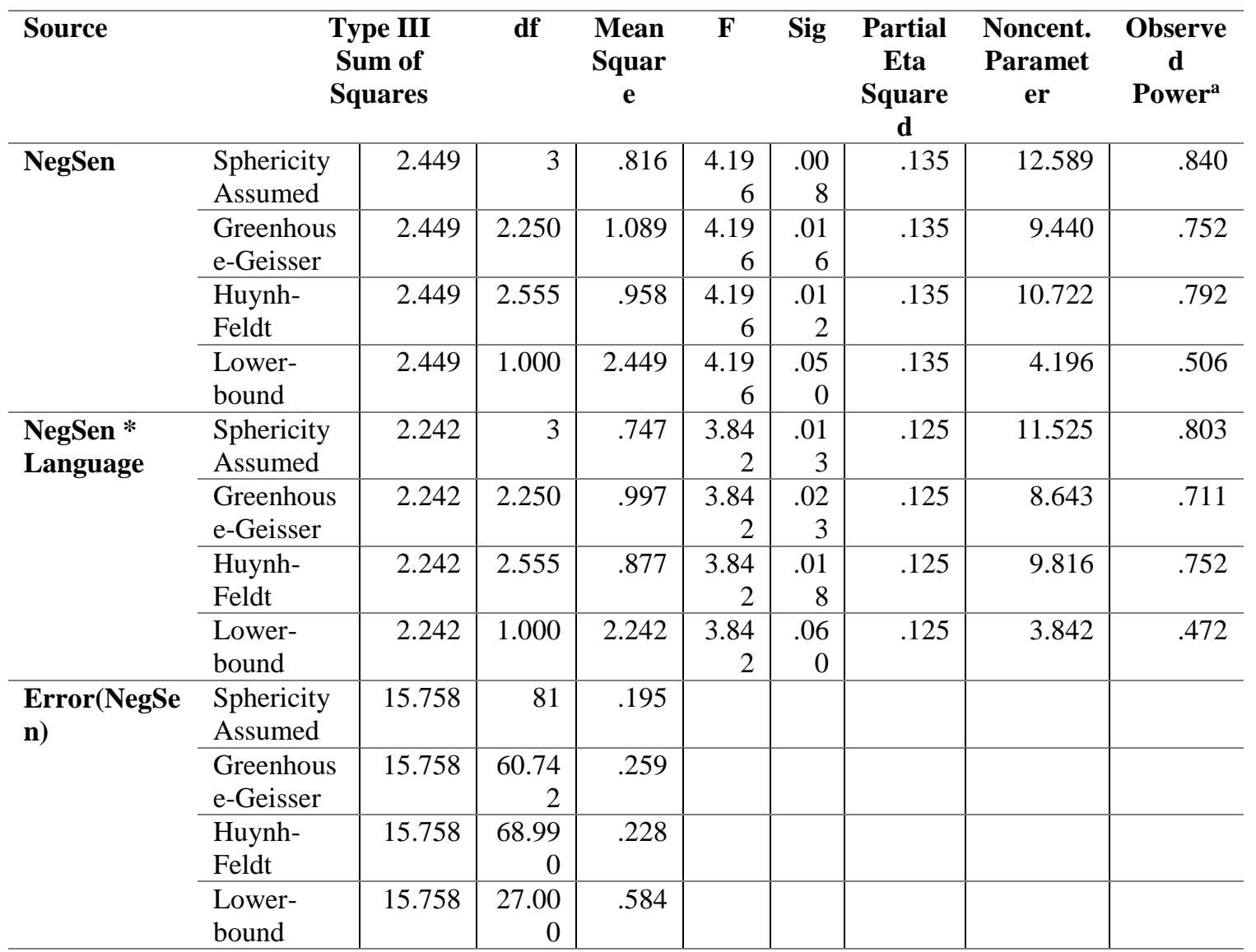

a. Computed using alpha $=.05$ 
Table 8

Mean Difference between Sentences with Negative Element Pairwise Comparison

\begin{tabular}{|c|c|c|c|c|c|c|}
\hline \multirow[t]{2}{*}{$\begin{array}{l}\text { (I) } \\
\text { NEGSEN }\end{array}$} & \multirow[t]{2}{*}{$\begin{array}{l}\text { (J) } \\
\text { NEGSEN }\end{array}$} & \multirow[t]{2}{*}{$\begin{array}{c}\text { MEAN } \\
\text { DIFFERENCE } \\
\text { (I-J) }\end{array}$} & \multirow[t]{2}{*}{$\begin{array}{c}\text { STD. } \\
\text { ERROR }\end{array}$} & \multirow[t]{2}{*}{ SIG. ${ }^{\mathbf{B}}$} & \multicolumn{2}{|c|}{$\begin{array}{l}\text { 95\% CONFIDENCE } \\
\text { INTERVAL FOR } \\
\text { DIFFERENCE }^{\mathrm{B}}\end{array}$} \\
\hline & & & & & Lower Bound & Upper Bound \\
\hline \multirow{3}{*}{$\mathrm{NEG}+\mathrm{V}$} & Aux Do & -.087 & .163 & .599 & -.422 & .248 \\
\hline & OBJ & $.279^{*}$ & .112 & .020 & .048 & .509 \\
\hline & Other & .229 & .123 & .073 & -.022 & .480 \\
\hline \multirow[t]{3}{*}{ AUX DO } & $\mathrm{Neg}+\mathrm{V}$ & .087 & .163 & .599 & -.248 & .422 \\
\hline & OBJ & $.366^{*}$ & .115 & .004 & .130 & .601 \\
\hline & Other & $.316^{*}$ & .121 & .015 & .067 & .565 \\
\hline \multirow[t]{3}{*}{ OBJ } & $\mathrm{Neg}+\mathrm{V}$ & $-.279^{*}$ & .112 & .020 & -.509 & -.048 \\
\hline & Aux Do & $-.366^{*}$ & .115 & .004 & -.601 & -.130 \\
\hline & Other & -.050 & .083 & .553 & -.221 & .121 \\
\hline \multirow[t]{3}{*}{ OTHER } & $\mathrm{Neg}+\mathrm{V}$ & -.229 & .123 & .073 & -.480 & .022 \\
\hline & Aux Do & $-.316^{*}$ & .121 & .015 & -.565 & -.067 \\
\hline & OBJ & .050 & .083 & .553 & -.121 & .221 \\
\hline
\end{tabular}

BASED ON ESTIMATED MARGINAL MEANS

*. THE MEAN DIFFERENCE IS SIGNIFICANT AT THE .05 LEVEL.

B. ADJUSTMENT FOR MULTIPLE COMPARISONS: LEAST SIGNIFICANT DIFFERENCE (EQUIVALENT TO NO ADJUSTMENTS). 


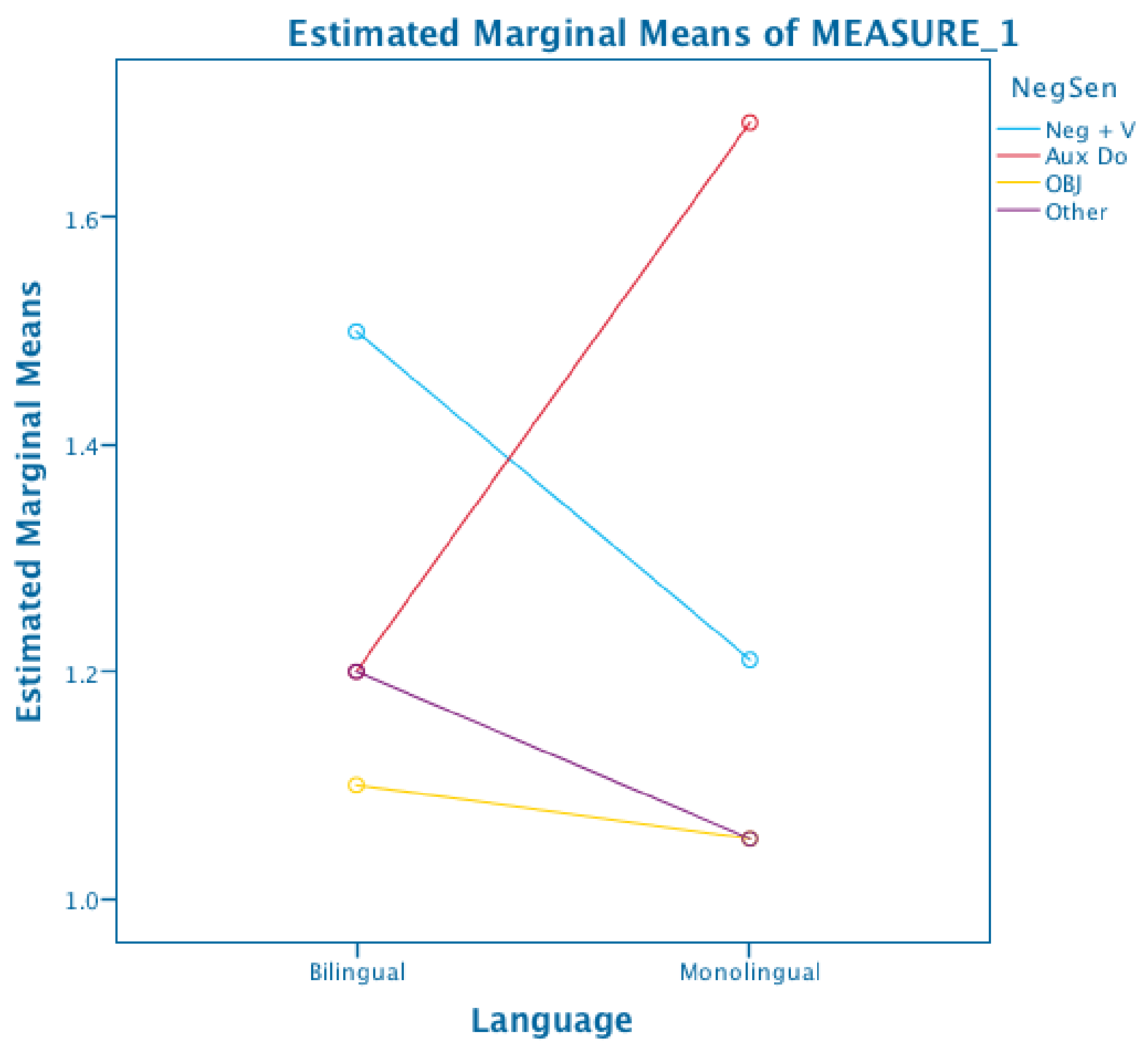

Figure 1. Means of the types of sentences with negative elements by language spoken 


\section{CHAPTER 5}

\section{DISCUSSION}

This study attempted to obtain information on the effect of a second language (i.e., Spanish/English) sentence structures on the construction of negatives forms in bilingual children. The question in this study asked if there are differences between bilingual and monolingual four to five-year-old children's construction of negative sentences. When bilingual children were prompted to respond to the specified question, the form NEG + U was used the most, compared to monolingual children who demonstrated to use the "Do" inclusion form the most. This indicated a significant difference and show that bilingual speakers demonstrate a different construction of negation sentences. The responses from the bilingual participants NEG + utterance seemed to reflect Spanish language constructions as this structure is consistent with Garcia (1977) and Lambert and Rawlings (1969) which proposes that Spanish constructions of negation follow the pattern $\mathrm{Neg}+$ utterance in the structure of the response "No have wheels".

The analysis also revealed that few bilinguals follow the "subject inclusion" structure in their responses which is consistent with Spanish structures of language (Liceras, Fuertes, \& de la Fuente, 2012). In addition, there were only a few responses from bilingual participants with the "Do" inclusion structure. 
In this study, it is concluded that the responses from the bilingual participants reflect Spanish language constructions.

The prediction for monolingual responses were consistent with the study replicated showing higher levels of " $D o$ " inclusion forms. It is suggested that the differences between the responses from monolinguals and bilingual construction of negation suggest the influence of a second language, in this case Spanish, on English negative constructions.

In regards to gender, participants were divided into four bilingual females and six bilingual males. The monolingual group was divided into 13 females and 6 males. The total number of females in the study were 17 and the number of males was 12 . Although this study does not focus on gender differences, it would be important to include this topic in future research.

\section{Conclusion}

This study aimed to investigate if those negation expressions reflected the influences of the second language structures and investigated if there was a significant difference from the construction of monolinguals. The responses obtained while collecting the data suggest that there is a trend of difference in the manner that monolinguals express negation when compared to the way bilinguals construct negatives.

Descriptive statistics reveal that there were four different types of sentences with negation used by both bilingual and monolingual participants.

A one-way repeated measures ANOVA was conducted to compare the effect of language spoken on speaker's production of the four types of sentences. The results of 
the ANOVA showed that both bilingual and monolingual participants use all four types but to a different extent.

Even though the study contained a small sample size and adjustments for unequal variances had to be made (Mauchly's Test was significant therefore report finding from Greenhouse-Geisser), bilinguals used more NEG + U (verb or subject) and monolinguals used more "Do" inclusion constructions.

It is important to highlight that this experiment contains certain limitations. Due to constrains during data collection, there was limited access to acquiring a larger group of participants and even an equal amount of monolingual and bilinguals. Additionally, not all conditions of the parent study were replicated in this pilot study, therefore generalization of results is unclear. Lastly, the present study data does not contain a variety of ages, therefore generalization of the results in different age children.

The significant difference between responses gives information on the trends of negation constructions between these two groups. This topic would benefit from further research to continue to uncover more information about language development in English/Spanish bilingual children. 
Appendix A

Parental Consent Form (English Version)

\section{RESEARCH STUDY INVITATION: THE CONSTRUCTION OF SENTENCES USING THE WORD "NO”, IN CHILDREN WHO SPEAK ENGLISH AND CHILDREN WHO SPEAK ENGLISH AND SPANISH}

Your child is being asked to participate in a research study. This form has important information about the reason for doing this study, what we will ask your child to do, and the way we would like to use information about your child if you choose to allow your child to participate in the study. Please read this form carefully and ask any questions you may have before agreeing to take part in the study.

\section{Why are you doing this study?}

Your child is being asked to participate in a research study about the construction of sentences using the word "no" in bilingual Spanish/English and monolingual English speakers 3-6 years old.

The purpose of the study is to observe how children who speak Spanish and English construct sentences using the word "no" in relation to children who speak only English.

\section{Where will this study be done?}

This study will be done at school under faculty/staff/parental or research advisor supervision.

\section{What will my child be asked to do if my child is in this study?}

Your child will be asked to identify a broken toy. No personal and/or sensitive questions will be asked. Participation in this study should take approximately 30 minutes.

We would like to video record your child as he/she responds to make sure that we accurately assess his/her responses to gain the necessary information. The researcher will keep these recordings private.

\section{What are the possible risks or discomforts to my child?}

Your child's participation in this study does not involve any physical or emotional risks beyond that of everyday life.

\section{What are the possible benefits for my child or others?}

Your child will not have any monetary benefit from being in this research study. This study is designed to learn more about language development in children. 
How will you protect the information you collect about my child, and how will that information be shared?

Results of this study may be used in publications and presentations. However, your name and/or your child's name will never be used. Your child will be referred to only by an assigned ID number given to him/her at the beginning of the study.

\section{Financial Information}

Participation in this study will involve no cost to you or your child.

\section{What are my child's rights as a research participant?}

Participation in this study is voluntary. Your child may withdraw from this study at any time and you and your child will not be penalized in any way for deciding to stop participation. If you and your child decide not to be in this study, this will not affect the relationship you and your child have with your child's school or Andrews University in any way.

\section{Who can I contact if I have questions or concerns about this research study?}

If you or your child have any questions, you may contact the researcher, Isabel Verduzco, via email (verduzci@andrews.edu) or cell phone (1-269-213-0406), the Supervising Professor, Dr. D'Jaris Coles-White at the Department of Speech Language Pathology \& Audiology or the Office of Research at Andrews University at:

Andrews University

Department of Speech Language Pathology

Scholarship

\& Audiology

Phone: (269) 471-3468

Email: speech@andrews.edu
Andrews University

Office of Research and Creative

Phone: (269) 471-6361

Email: irb@andrews.edu 


\section{Consent Form for Study on the Construction of "No" Sentences in 3-6 year olds}

\section{Parental Permission for Child's Participation in Research}

I have read the consent form focused on observing the construction of sentences using the word "no" in bilingual Spanish/English and monolingual English speakers 3-6 years old. I have been told who to contact if I had any additional questions or concerns.

Having read the information provided, I, give permission

for

(parent/guardian name)

(child's name)

to participate in this research study.

Parent/Legal Guardian's Name (printed)

Relationship

Parent/Legal Guardian's Signature

Date 


\section{INVITACION PARA INVESTIGACION: LA CONSTRUCCION DE FRASES QUE USAN LA PALABRA "NO" EN NIÑOS QUE HABLAN INGLES Y NINOS QUE HABLAN INGLES Y ESPAÑOL}

Su niño está siendo invitado a participar en un estudio de investigación. Este formulario tiene información importante acerca de la razón para hacer este estudio, lo que se pide del niño, y la forma en que nos gustaría utilizar la información acerca de su hijo si usted decide permitir que el/ella participe en el estudio. Por favor, lea cuidadosamente este formulario y haga cualquier pregunta que usted pueda tener antes de aceptar participar en el estudio.

¿Por qué se está haciendo este estudio?

Su hijo está siendo invitado a participar en un estudio de investigación sobre como niños bilingües en Español/Inglés y monolingües hablantes solo de inglés construyen oraciones que incluyen la palabra "no".

El objetivo del estudio es observar diferencias entre las construcciones de oraciones que incluyen la palabra "no" en niños entre 3-6 años.

¿En donde se hara este estudio?

Este estudio se hará en la escuela bajo la supervision de el profesor o el padre/madre o de el consejero de investigación.

¿Que se le pedira a mi niño si participa en este estudio?

Se le pedirá a su hijo identifique un juguete roto. No se formularan preguntas personales y/o sensibles. La participación en este estudio durará media hora.

Nos gustaría grabar en vídeo a su hijo para asegurarse de que podemos evaluar con precisión toda la información. Los investigadores mantendrán estas grabaciones en un lugar privado.

¿Cuáles son los posibles riesgos que este estudio representa a mi hijo?

La participación del niño en este estudio no implica ningún riesgo físico o emocional para su hijo más allá de la vida cotidiana.

¿Cuáles son los posibles beneficios para mi hijo u otros? 
Su hijo no recibira ningún beneficio directo de este estudio de investigación. Los resultados de este estudio serán utilizados para aprender mas de el desarrollo del lenguaje.

¿Cómo proteger la información recopilada acerca de mi hijo, y cómo esa información va a ser compartida?

Los resultados de este estudio pueden ser utilizados en publicaciones y presentaciones. Sin embargo, su nombre y/o el nombre de su hijo nunca será utilizados.

\section{Información Financiera}

La participación en este estudio no supondrá ningún costo para usted o su hijo.

¿Cuáles son mis derechos del niño como participante de la investigación?

La participación en este estudio es voluntaria. Su hijo puede retirarse del estudio en cualquier momento -- usted y su niño no serán penalizados en ninguna manera por decidir detener la participación. Si usted y su hijo deciden no estar en el presente estudio, esto no afectará a la relación que usted y su hijo tienen con la escuela de su hijo en modo alguno

\section{¿A quién puedo contactar si tengo preguntas o inquietudes acerca de este estudio de investigación?}

Si usted o su hijo tiene alguna pregunta, puede ponerse en contacto con los investigadores.

Información de Contacto: Isabel Verduzco, (323)823-5867, verduzci@andrews.edu

Si usted tiene alguna pregunta acerca de los derechos de su hijo como participante en esta investigación, puede ponerse en contacto con la Universidad Andrews:

Department of Speech Language Pathology \& Audiology

4195 Administration Dr.

Teléfono: (269)-471-3468

Correo electrónico: Speech@andrews.edu 
FORMULARIO DE PERMISO PARA EL ESTUDIO DE LA CONSTRUCCION DE ORACIONES CON LA PALABRA "NO" POR NIÑOS BILINGUES Y NO

\section{BILINGUES}

\section{Permiso para la Participación del Niño en la Investigación:}

He leído este formulario acerca de el estudio de la construccion de oraciones que contienen la palabra "no" en niños bilingues y no bilingues entre 3 y 6 años. Sé a quien contactar si tengo preguntas.

Habiendo leído este formulario, yo doy mi

(nombre del padre/madre)

consentimiento para que mi hijo participe en el estudio descrito

anteriormente.

$$
\text { (nombre del niño) }
$$

Nombre de Padres/Guardian legal (impreso)

Relación

Firma de los Padres

Fecha 


\section{ANDREWS UNIVERSITY DEPARTMENT OF SPEECH LANGAUGE PATHOLOGY \& AUDIOLOGY ASSESNT FORM FOR CHILD'S RESEARCH PARTICIPATION}

I am doing a study to learn about the development of language in bilingual Spanish/English and monolingual English speakers. We are asking you to help because we don't know very much about how kids 3-6 years old develop language, especially the area of negation.

If you agree to be in our study, we are going to ask you to complete a short test and then show you a toy and ask a yes/no question about it.

You can ask questions about this study at any time. If you decide at any time not to finish, you can ask us to stop.

The questions we will ask are only about what you think. There are no right or wrong answers because this is not a test.

If you sign this paper, it means that you have read this and that you want to be in the study. If you don't want to be in the study, don't sign this paper. Being in the study is up to you, and no one will be upset if you don't sign this paper or if you change your mind later.

Your printed name: Date

Printed name of person obtaining consent: Date 


\section{Formulario de consentimiento}

Este estudio se esta haciendo para conocer el desarrollo del lenguaje en niños bilingües que hablan Español/Inglés y niños monolingües hablantes de solo Inglés. Estamos solicitando su participacion para conocer mas acerca de cómo niños entre 3-6 años desarrollan areas del lenguaje, especialmente en el área de la negación.

Si usted acepta participar en nuestro estudio, le pediremos que complete unos cortos questionarios y luego te mostraremos un juguete y te haremos una pregunta para responder con sí/no.

Usted puede hacer preguntas acerca de este estudio en cualquier momento. Si en algun momento usted decide no continuar, nos puede avisar y descontinuaremos todas las pruebas.

En las preguntas planteadas sólo preguntaremos acerca de lo que usted piensa. No hay respuestas correctas o incorrectas, porque esto no es una prueba.

Si firma este documento, significa que ha leído la presente y que desea participar en el estudio. Si decide que no quiere participar en el estudio, no firme este documento. Su participation en el estudio es voluntaria, y nadie se molestara si usted no firma este documento o si cambia de opinión más adelante. Muchas Gracias!

Su nombre impreso: Fecha

Nombre impreso de la persona que recibe el consentimiento: 


\section{REFERENCE LIST}

Ahmad, K. (2002). Don't just say “no”: Developmental sequence of negation. Retrieved from httpzl/dspace.wrlc.org/handle/l,961,5224.

Anaya, J. B., Peña, E. D., \& Bedore, L. M. (2016). Where Spanish and English come together: A two dimensional bilingual approach to clinical decision making. Perspectives of the ASHA Special Interest Groups, 1(14), 3-16.

Aud, S., Hussar, W., Johnson, F., Kena, G., Roth, E., Manning, E., ... \& Zhang, J. (2012). The condition of education 2012. NCES 2012-045. National Center for Education Statistics.

Bialystok, E., Craik, F. I., \& Luk, G. (2012). Bilingualism: Consequences for mind and brain. Trends in cognitive sciences, 16(4), 240-250.

Bloom, L. (1970). Language development: Form and function in emerging grammars. MIT Research Monograph, 59.

Brogan, F. D., \& Son, J. (2015). Native language transfer in target language usage: An exploratory case study. Voices, 3(1).

Cameron-Faulkner, T., Lieven, E., \& Theakston, A. (2007). What part of no do children not understand? A usage-based account of multiword negation. Journal of Child Language, 34(02), 251-282.

Capdevila i Batet, M., \& Llinàs i Grau, M. (1995). The acquisition of negation in English. Atlantis, 27-44.

Castilla, A. P., Restrepo, M. A., \& Perez-Leroux, A. T. (2009). Individual differences and language interdependence: A study of sequential bilingual development in Spanish-English preschool children. International Journal of Bilingual Education and Bilingualism, 12(5), 565-580.

Chapman, C., Laird, J., Ifill, N., \& KewalRamani, A. (2011). Trends in high school dropout and completion rates in the United States: 1972-2009. Compendium report. NCES 2012-006. National Center for Education Statistics.

Choi, S. (1988). The semantic development of negation: A cross-linguistic longitudinal study. Journal of Child Language, 15(3), 517-531. 
Conboy, B. T., \& Thal, D. J. (2006). Ties between the lexicon and grammar: Crosssectional and longitudinal studies of bilingual toddlers. Child development, 77(3), 712-735.

Cycyk, L. M., Bitetti, D., \& Hammer, C. S. (2015). Maternal depressive symptomatology, social support, and language development of bilingual preschoolers from low-income households. American Journal of SpeechLanguage Pathology, 24(3), 411-425.

Déprez, V., \& Pierce, A. (1993). Negation and functional projections in early grammar. Linguistic Inquiry, 25-67.

Drodz, K. F. (2002). Negative DPs and elliptical negation in child English. Language Acquisition, 10(2), 77-122.

Dulay, H. C., \& Burt, M. K. (1972). Goofing: An indicator of children's second language learning strategies. Language learning, 22(2), 235-252.

Duran, B. J., \& Weffer, R. E. (1992). Immigrants' aspirations, high school process, and academic outcomes. American Educational Research Journal, 29(1), 163-181.

Fenson, L., Dale, P. S., Reznick, J. S., Bates, E., Thal, D. J., Pethick, S. J., ... \& Stiles, J. (1994). Variability in early communicative development. Monographs of the Society for Research in Child Development, i-185.

Garcia, E. (1977). The study of early childhood bilingualism: Strategies for linguistic transfer research. Chicano Psychology, 141.

García, E. E., \& Miller, L. S. (2008). Findings and recommendations of the national task force on early childhood education for Hispanics. Child Development Perspectives, 2(2), 53-58.

Gilkerson, J., Hyams, N., \& Curtiss, S. (2004). On the scope of negation: More evidence for early parameter setting. LOT Occasional Series, 3, 175-185.

Givón, T. (1978). Negation in language: Pragmatics, function, ontology. Syntax and Semantics, 9(69), 105.

Gutiérrez-Clellen, V. F., Restrepo, M. A., Bedore, L., Peña, E., \& Anderson, R. (2000). Language sample analysis in Spanish-speaking children: Methodological considerations. Language, Speech, and Hearing Services in Schools, 31(1), 88-98.

Haegeman, L. (1995). The syntax of negation (Vol. 75). Cambridge, England: Cambridge University Press. 
Hammer, C. S., Komaroff, E., Rodriguez, B. L., Lopez, L. M., Scarpino, S. E., \& Goldstein, B. (2012). Predicting Spanish-English bilingual children's language abilities. Journal of Speech, Language, and Hearing Research, 55(5), 1251-1264.

Hemphill, F. C., \& Vanneman, A. (2011). Achievement gaps: How Hispanic and White students in public schools perform in mathematics and reading on the national assessment of educational progress. Statistical analysis report. NCES 2011459. National Center for Education Statistics.

Horn, L. (2001). A natural history of negation. Stanford, CA: CSLI Publications

Irvine, M. G. (2005). Developmental stages of negation in one learner's interlanguage: A case study. (Doctoral dissertation). Portland State University: Portland, OR.

Kapantzoglou, M., Restrepo, M. A., Gray, S., \& Thompson, M. S. (2015). Language ability groups in bilingual children: A latent profile analysis. Journal of Speech, Language, and Hearing Research, 58(5), 1549-1562.

Kindler, A. L. (2002). Survey of the states' limited English proficient students and available educational programs and services: 2000-2001 summary report. Washington, DC: National Clearinghouse for English Language Acquisition, 8.

Klima, E., \& Bellugi, U. (1966). Syntactic regularities in the speech of children. Psycholinguistic Papers, 3765.

Laka, I. (1994). On the syntax of negation: Outstanding dissertations in linguistics. New York, NY and London, England: Routledge.

Lambert, W. E., \& Rawlings, C. (1969). Bilingual processing of mixed-language associative networks. Journal of Verbal Learning and Verbal Behavior, 8(5), 604609.

Larrañaga, P., Treffers-Daller, J., Tidball, F., \& Ortega, M. C. G. (2012). L1 transfer in the acquisition of manner and path in Spanish by native speakers of English. International Journal of Bilingualism, 16(1), 117-138.

Liceras, J. M., Fuertes, R. F., \& de la Fuente, A. A. (2012). Overt subjects and copula omission in the Spanish and the English grammar of English-Spanish bilinguals: On the locus and directionality of interlinguistic influence. First Language, 32(12), 88-115.

Lindholm, K., \& Padilla, A. (1977). Bilingual children's use of language mixing and switching. In Proceedings of the second annual Los Angeles second language research forum. (1st, Los Angeles, California, February 11-13, 1977) 
Lindholm, K. J., \& Padilla, A. M. (1978). Language mixing in bilingual children. Journal of Child Language, 5(02), 327-335.

Madrid, D., \& Garcia, E. E. (1981). Development of negation in bilingual Spanish/English and monolingual English speakers. Journal of Educational Psychology, 73(5), 624.

Madrid, D., \& García Sánchez, E. (2001). Content-based second language teaching. Present and future trends in TEFL. Almería: Secretariado de Publicaciones de la Universidad de Almería, 101-134.

Marchman, V. A., Martínez-Sussmann, C., \& Dale, P. S. (2004). The language-specific nature of grammatical development: Evidence from bilingual language learners. Developmental Science, 7(2), 212-224.

McGuire, S. (2011). US Department of Agriculture and US Department of Health and Human Services, Dietary Guidelines for Americans, 2010. Washington, DC: US Government Printing Office, January 2011. Advances in Nutrition: An International Review Journal, 2(3), 293-294.

McNeill, D., \& McNeill, N. B. (1967). A question in semantic development-What does a child mean when he says "no". Center for Research on Language and Language Behavior. Ann Arbor, MI: University of Michigan.

Ouhalla, J. (1990). Sentential negation, relativised minimality and the aspectual status of auxiliaries. The Linguistic Review, 7(2), 183-231.

Padilla, A. M., \& Lindholm, K. J. (1976). Development of interrogative, negative and possessive forms in the speech of young Spanish/English bilinguals. Bilingual Review/La Revista Bilingüe, 122-152.

Pea, R. D. (1980). The development of negation in early child language. The Social Foundations Of Language And Thought, 156-186.

Reardon, S. F., \& Galindo, C. (2009). The Hispanic-White achievement gap in math and reading in the elementary grades. American Educational Research Journal, 46(3), 853-891.

Restrepo, M. A. (1998). Identifiers of predominantly Spanish-speaking children with language impairment. Journal of Speech, Language, and Hearing Research, 41(6), 1398-1411.

Rice, M. L., Wexler, K., Marquis, J., \& Hershberger, S. (2000). Acquisition of irregular past tense by children with specific language impairment. Journal of Speech, Language, and Hearing Research, 43(5), 1126-1144. 
Ryff, C. D., \& Keyes, C. L. M. (1995). The structure of psychological well-being revisited. Journal of personality and social psychology, 69(4), 719.

Saffran, J. R., Senghas, A., \& Trueswell, J. C. (2001). The acquisition of language by children. Proceedings of the National Academy of Sciences, 98(23), 12874-12875.

Steinberg, D. D. (1993). An introduction to psycholinguistics. London, England: Longman.

Steinberg, D. D., Nagata, H., \& Aline, D. P. (2013). Psycholinguistics: Language, mind and world. Harlow, England and New York, NY: Longman

Sun-Alperin, M. K., \& Wang, M. (2011). Cross-language transfer of phonological and orthographic processing skills from Spanish L1 to English L2. Reading and Writing, 24(5), 591-614.

Thornton, R., \& Tesan, G. (2013). Sentential negation in early child English. Journal of Linguistics, 49(2), 367-411.

van der Lely, H. K., Rosen, S., \& McClelland, A. (1998). Evidence for a grammarspecific deficit in children. Current Biology, 8(23), 1253-1258.

van der Lely, H. K. (2005). Domain-specific cognitive systems: Insight from grammatical-SLI. Trends in Cognitive Sciences, 9(2), 53-59

van Gelderen, E. (2010). Negative concord and the negative cycle in the history of English. Language Change And Variation From Old English to Late Modern English: A Festschrift for Minoji Akimoto, 35-58.

Walton-Ramirez, A. (2015). Negation and NegP developmental steps in bilingual Spanish/English children. (Doctoral dissertation). Arizona State University: Tempe, AZ.

Wode, H. (1977). Four early stages in the development of LI negation. Journal of Child Language, 4(01), 87-102.

Youssef, I. (2015). Phases in L1 acquisition of negation: A comparative study of Cairene Arabic and English. SKASE Journal of Theoretical Linguistics, 12(4).

Zanuttini, R. (1997). Negation and clausal structure: A comparative study of romance languages. Oxford, United Kingdom: Oxford University Press.

Zeijlstra, H. (2004). Sentential negation and negative concord. (Doctoral dissertation). Retrieved from ProQuest Digital Dissertations. University of Amsterdam. 
Zobl, H. (1980). Developmental and transfer errors: Their common basis and (possibly) differential effects on subsequent learning. Tesol Quarterly, 469-479. 